Transactions of the American Fisheries Society, Vol. 125, No. 1, 1996, pp. 27-41. http://afs.allenpress.com

http://afs.allenpress.com/archive/1548-8659/125/1/pdf/i1548-8659-125-1-27.pdf Online ISSN: 1548-8659

Print ISSN: 0002-8487

DOI: 10.1577/1548-8659(1996)125<0027:QLAGSZ>2.3.CO;2

(C) American Fisheries Society 


\title{
Quantifying Linkages among Gizzard Shad, Zooplankton, and Phytoplankton in Reservoirs
}

\author{
John M. DetTmers ANd Roy A. STEIN \\ Aquatic Ecology Laboratory \\ Department of Zoology, The Ohio State University \\ 1314 Kinnear Road, Columbus, Ohio 43212-1194, USA
}

\begin{abstract}
Food webs in northern temperate lakes frequently exhibit tightly linked interactions between adjacent trophic levels that lead to top-down effects from piscivores to phytoplankton. To determine if these interactions occur in reservoirs dominated by an omnivorous planktivore, gizzard shad Dorosoma cepedianum, we experimentally quantified crustacean zooplankton and phytoplankton responses to age-0 gizzard shad (23-90 mm total length) at four gizzard shad densities across three reservoirs, each with a different level of crustacean zooplankton productivity. Age-0 gizzard shad exerted strong top-down effects on crustacean zooplankton, eliminating it from most enclosures within 2 weeks. This decline in crustacean zooplankton did not lead to increases in phytoplankton unless Daphnia spp. were initially abundant. As detritivores, gizzard shad can remain abundant when planktonic food resources are depleted. This trophic decoupling probably allows gizzard shad to structure reservoir food webs by overconsumption of crustacean zooplankton, which in turn may compromise recruitment of sport fishes with zooplanktivorous larvae. In our view, the potential for increasing crustacean zooplankton density by controlling gizzard shad with stocked predators will be limited to reservoirs where age-0 gizzard shad density can be reduced below $10 \mathrm{fish} / \mathrm{m}^{3}$ and where daily zooplankton productivity exceeds $220 \mathrm{mg} / \mathrm{m}^{3}$.
\end{abstract}

The trophic cascade hypothesis is a useful conceptual framework for investigating the processes governing community interactions in natural lakes (Kitchell and Carpenter 1993). This hypothesis provides an intuitive basis for understanding topdown effects of fishes on lower trophic levels at given nutrient levels (Carpenter et al. 1987; McQueen et al. 1989; Carpenter and Kitchell 1993). This framework also can provide insight into strategies for managing lake communities (Shapiro and Wright 1984; Benndorf 1990; Kitchell 1992).

Top-down trophic interactions are quite predictable at the piscivore-planktivore and planktivore-zooplankton levels but are more equivocal at the zooplankton-phytoplankton level (DeMelo et al. 1992). The unpredictable strength of top-down responses at the zooplankton-phytoplankton link may be due primarily to lake trophic status (McQueen et al. 1986); more eutrophic lakes are less likely to exhibit top-down effects unless large Daphnia spp. are abundant (Vanni et al. 1990; McQueen et al. 1992). However, rigorous experimental tests of the potential interaction between lake trophic state and planktivore density have revealed no influence on phytoplankton biomass (reviewed by Lancaster and Drenner 1990; DeMelo et al. 1992).

In our view, trophic interactions in reservoirs depart from the strongly linked interactions com- mon to northern lakes, in which native predators can control prey fish abundance and, in turn, modify lower trophic levels (Carpenter et al. 1987; Lyons 1987; McQueen et al. 1989). In reservoirs, for example, native predators frequently do not control the abundance of prey fishes, especially shad Dorosoma spp. (Orth 1980; Summers and Axon 1980; Filipek 1982; Willis and Jones 1986). Although gizzard shad $D$. cepedianum are preferred prey (Johnson et al. 1988; Wahl and Stein 1988), high fecundity (Vondracek and LeHew 1991), fast growth, and large adult size limit their vulnerability to predators (Adams and DeAngelis 1987; Johnson et al. 1988; Hambright et al. 1991; Stein et al., in press). In Ohio reservoirs, only $20 \%$ of gizzard shad production is consumed by predators (Carline et al. 1984; Johnson et al. 1988).

Further, gizzard shad impose their own control on lower trophic levels (Drenner et al. 1982a, 1982b; Dettmers and Stein 1992; DeVries and Stein 1992) without being strongly regulated by zooplankton and phytoplankton abundance. Age0 gizzard shad longer than $25 \mathrm{~mm}$ total length (TL), when sufficiently abundant, can virtually eliminate crustacean zooplankton in reservoirs (Dettmers and Stein 1992; DeVries and Stein 1992) and then switch to feeding on phytoplankton and detritus (Miller 1960; Bodola 1966). Thus, age-0 gizzard shad can reduce growth, survival, and abundance of other planktivorous age- 0 fishes 
by exploitative competition for zooplankton (Guest et al. 1990; DeVries et al. 1991) while maintaining high population densities.

Gizzard shad longer than $100 \mathrm{~mm}$ feed primarily on detritus (Mundahl and Wissing 1988; Mundahl 1991). However, if abundant, this life stage also can regulate zooplankton and phytoplankton. In mesocosm experiments, adult gizzard shad increased primary productivity and reduced crustacean zooplankton abundance, effects which were stronger in more productive mesocosms (Drenner et al., in press). By feeding on detritus, gizzard shad may regulate zooplankton and phytoplankton by moving nutrients from sediments to the pelagia, where they can be used by phytoplankton (Vanni 1995). As a result, all life stages of gizzard shad may regulate reservoir communities via complex "middle-out" processes that affect both higher and lower trophic levels (Stein et al., in press).

Given their dramatic effects on food webs, reduction of gizzard shad numbers by large, nonresident predators may be an attractive option for resource managers who seek to improve sportfishing opportunities and water clarity by increasing zooplankton abundance. These predators must consume sufficient gizzard shad to release zooplankton populations from planktivore control, thereby increasing recruitment potential of resident sport fishes and increasing grazing pressure on phytoplankton.

If zooplankton increases as gizzard shad abundance declines, we expect more zooplankton to be available for early life stages of sport fishes and to increase grazing pressure on phytoplankton. Here, we describe how several densities of age-0 gizzard shad influenced crustacean zooplankton abundance in reservoirs with different capacities for producing zooplankton.

\section{Study Area}

Clark Lake in Clark County, west-central Ohio, supports high zooplankton productivity. It is a 40ha shallow, turbid reservoir with $4.5 \mathrm{~km}$ of shoreline, a maximum depth of $2 \mathrm{~m}$, and Secchi depths of $25-75 \mathrm{~cm}$. Kokosing Lake in Knox County, central Ohio, supports intermediate zooplankton productivity. It is a 65-ha, shallow reservoir with $7.5 \mathrm{~km}$ of shoreline, a maximum depth of $4.9 \mathrm{~m}$, and Secchi depths of 40-110 cm. Knox Lake, also in Knox County, supports low zooplankton productivity. It is a 225-ha reservoir with $19.2 \mathrm{~km}$ of shoreline, a maximum depth of $9.6 \mathrm{~m}$, and Secchi depths of $60-140 \mathrm{~cm}$. Rooted vegetation was rare or nonexistent in all lakes. Fish communities con-
TABLE 1.-Design of enclosure experiments in three Ohio reservoirs, 1991-1992. Reservoirs were chosen to reflect the range of zooplankton productivity in Ohio. A larval gizzard shad food consumption model (Dettmers and Stein 1992) was used to determine densities of age-0 gizzard shad ( $23 \mathrm{~mm}$ total length) that provided an increasing challenge to zooplankton production in each reservoir.

\begin{tabular}{|c|c|c|c|c|c|}
\hline \multirow[b]{2}{*}{ Reservoir } & \multirow[b]{2}{*}{ Year } & \multirow{2}{*}{$\begin{array}{l}\text { Zooplank- } \\
\text { ton pro- } \\
\text { ductivity }\end{array}$} & \multicolumn{2}{|c|}{$\begin{array}{l}\text { Treatment densities } \\
\text { gizzard shad/m } \mathrm{m}^{3}\end{array}$} & \multirow{2}{*}{$\begin{array}{l}\text { Repli- } \\
\text { cates } \\
\text { per } \\
\text { treat- } \\
\text { ment }\end{array}$} \\
\hline & & & Planned & Resultant & \\
\hline Clark & 1992 & High & $0,12,25,50$ & $\begin{array}{c}12,31,43, \\
41\end{array}$ & 4 \\
\hline Kokosing & 1991 & Medium & $0,5,10,20$ & $0,4,9,17$ & 3 \\
\hline Knox & 1992 & Low & $0,3,6,12$ & $0,5,7,11$ & 4 \\
\hline
\end{tabular}

sisted primarily of gizzard shad, largemouth bass Micropterus salmoides, crappies Pomoxis spp., sunfishes Lepomis spp., yellow perch Perca flavescens, channel catfish Ictalurus punctatus, common carp Cyprinis carpio, and bullheads Ameiurus spp. We chose these lakes because sampling in 1987-1991 (Bremigan et al. 1991; Dettmers and Stein 1992) revealed that their crustacean zooplankton production was representative of the range encountered in Ohio reservoirs.

\section{Methods}

We placed 12 floating enclosures $(1.1 \mathrm{~m}$ in diameter, $1 \mathrm{~m}$ deep, and $1 \mathrm{~m}^{3}$ in volume, excluding sediments) in Kokosing Lake (May 8, 1991), 16 enclosures in Clark Lake (May 12, 1992), and 16 enclosures in Knox Lake (May 13, 1992). Enclosures were filled with lake water before larval fish were present, permitting crustacean zooplankton assemblages to develop for about 5 weeks without fish predation. We sampled zooplankton and phytoplankton in each enclosure weekly during MayJuly with four pooled hauls of a tube sampler (7.2 $\mathrm{cm}$ inside diameter; DeVries and Stein 1991). Zooplankton were filtered through a 54- $\mu \mathrm{m}$-mesh net and preserved in $4 \%$ sucrose-formalin (Haney and Hall 1973).

In all lakes, we randomly assigned enclosures to four treatment levels (Table 1). Gizzard shad treatment densities were chosen to increasingly challenge crustacean zooplankton persistence at a given level of zooplankton production. We used our larval gizzard shad food consumption model to predict consumption by different densities of 25-mm TL gizzard shad (Dettmers and Stein 1992), from which we established the range of fish densities to be added to enclosures. Specific fish 
densities were calculated such that their estimated zooplankton consumption bounded preliminary estimates of crustacean zooplankton production in a random sample of enclosures ( $N=3$ per lake) just before fish were added. Gizzard shad $(23 \mathrm{~mm}$ TL) were collected with buckets and immediately added to enclosures on June 13, 1991 (Kokosing), June 16, 1992 (Clark), and June 18, 1992 (Knox). This design provided a realistic test of the capacity for crustacean zooplankton communities protected from predation for 5 weeks to persist in the face of gizzard shad consumption. Based on previous experience handling $25-\mathrm{mm}$ gizzard shad, we assumed handling mortality to be $25-30 \%$; thus, we added $0,7,13$, and $26 \mathrm{fish} / \mathrm{m}^{3}$ to Kokosing enclosures; $0,16,32$, and $62 \mathrm{fish} / \mathrm{m}^{3}$ to Clark enclosures; and $0,4,8$, and $16 \mathrm{fish} / \mathrm{m}^{3}$ to Knox enclosures to generate our expected treatment densities. We evaluated our estimated handling mortality at the time of gizzard shad addition in each lake by adding 50 fish to each of two 120-L containers. After $24 \mathrm{~h}$, we drained the containers and counted and measured surviving fish to estimate mortality and the initial size of the gizzard shad. Final treatment densities differed from expected densities because of differences in gizzard shad survival among enclosures.

All enclosures were inspected weekly for holes. High winds caused holes to develop rapidly within $10 \mathrm{~cm}$ of the water line in most enclosures in Clark and Knox lakes. Beginning on May 28, we used waterproof tape to repair holes and reinforce weak areas. By the time gizzard shad were added, no new holes had developed. However, during May 28-June 16, larval gizzard shad entered all enclosures in Clark Lake and nine enclosures in Knox Lake by moving from the lake through holes in enclosures. With a spotlight at night, we found 16 gizzard shad in Clark Lake enclosures, and 1-3 shad in Knox Lake enclosures designated to receive gizzard shad.

Because gizzard shad could not be removed without destroying the enclosures, we did not adjust our gizzard shad addition scheme, except to be certain that we had fishless enclosures in Knox Lake. In Knox Lake, we allowed the nine enclosures already containing gizzard shad to receive additional gizzard shad according to our original design (Table 1).

Gizzard shad consumed crustacean zooplankton for 4-5 weeks in the enclosures. In Kokosing Lake, we counted zooplankton from June 12 to July 10. After July 10, 6 of 12 Kokosing enclosures were destroyed in a wind storm. We collected data for overall fish survival and growth when the remaining intact enclosures were drained on July 24-25, 1991. Enclosures were drained on July 15, 1992, in Knox Lake and on July 21, 1992, in Clark Lake. All remaining gizzard shad were counted and measured (nearest millimeter).

To compare dynamics of organisms in the lake with those in enclosures, we collected crustacean zooplankton and ichthyoplankton weekly from Kokosing Lake May 3-October 1, 1991, from Clark Lake May 7-September 26, 1992, and from Knox Lake May 4-August 11, 1992. Zooplankton were collected from three sites per lake with a 2 $\mathrm{m}$ tube sampler ( $33.5 \mathrm{~L}$ per site) and filtered through a $54-\mu \mathrm{m}$-mesh net: densities were averaged across sites to generate a mean for each date. We collected ichthyoplankton by towing a 0.75 $\mathrm{m}$-diameter, metered ichthyoplankton net $(500-\mu \mathrm{m}$ mesh) at the surface at $1.0-1.5 \mathrm{~m} / \mathrm{s}$ for $3-5 \mathrm{~min}$; two replicate tows were taken on each date. Larvae were preserved immediately in 10\% formalin, returned to the laboratory, and identified, counted, and measured (up to 50 per species, nearest millimeter TL).

Only crustacean zooplankton were counted in the laboratory (Stahl and Stein 1994); hence, in the remaining text, "zooplankton" refers to crustacean zooplankton. Up to 20 individuals of each taxon in a sample were measured (nearest 0.01 $\mathrm{mm}$ ) with a digitizing tablet viewed through a microscope drawing tube. These measurements provided size distributions through time and allowed us to calculate biomass from taxon-specific, length-dry weight regressions (Dumont et al. 1975; Bottrell et al. 1976; G. G. Mittelbach, Kellogg Biological Station, Michigan State University, unpublished data). Phytoplankton were concentrated by filtering through a $0.45-\mu \mathrm{m}$-pore filter; they were then placed on a cover slip and cleared with 2-hydroxypropyl methacrylate. Cover slips were dried for $12 \mathrm{~h}$, mounted on a slide $(N$ $=3$ slides per sample), and counted with an Olympus BH-2 compound microscope with Nomarski optics at magnifications of $200 \times$ and $400 \times$. At least 15 fields were counted at each magnification to achieve a coefficient of variation of less than 10\% (St. Amand 1990).

We calculated zooplankton production as the increase in mass of existing individuals plus the number of eggs produced each week (Culver and DeMott 1978). Temperature-dependent growth and egg development equations were used to determine the time individuals spent in each stage (DeMott 1976; Bean 1980). Zooplankton growth plus fe- 
cundity provided production estimates for each taxon. Taxon-specific production was then summed across taxa to generate estimates of total zooplankton production for each weekly interval.

We analyzed treatment effects for total zooplankton density, size, biomass, production, and taxon-specific density with split-plot repeatedmeasures analysis of variance (Maceina et al. 1994). Treatment effects were compared from the last date that all enclosures were fishless (midJune) until we ended experiments (mid-July). Data for zooplankton density, biomass, production, edible phytoplankton biomass, and inedible phytoplankton biomass were $\log _{e}(x+1)$-transformed before statistical analysis to reduce heteroscedasticity and generate normally distributed residuals.

\section{Results}

\section{Enclosure Experiments}

We used our measure of the mean edible phytoplankton biovolume in enclosures during JuneJuly to characterize productivity among lakes. Edible phytoplankton biovolume differed among enclosures from the three lakes (ANOVA; $F=14.22$; df $=1,165 ; P<0.0001$ ). Clark Lake enclosures were most productive, providing twice the biovolume of edible phytoplankton of Kokosing Lake enclosures, and four times that of Knox Lake enclosures.

Clark Lake.-Based on open-lake samples from Clark Lake, zooplankton did not peak during spring, never exceeding 100 individuals/L, through June 28 (Figure 1A). Zooplankton density peaked at $187 / \mathrm{L}$ on July 11 , compared with zooplankton peaks of more than $400 / \mathrm{L}$ in all enclosures. Dominant zooplankton in the lake were cyclopoid copepods, calanoid copepods, and copepod nauplii. Larval gizzard shad first appeared on May 13 and reached a peak density of $38 / \mathrm{m}^{3}$ on June 28 , with a secondary peak of $24 / \mathrm{m}^{3}$ on May 27 (Figure 1A).

Zooplankton density in Clark Lake enclosure treatments initially was less than $75 / \mathrm{L}$ during May 12-19, increased to more than 300/L during May 20-June 9, and remained above that level through June 16, after which gizzard shad were added to enclosures (Figure 1B). Daphnia spp., copepod nauplii, and calanoid copepods were dominant; cyclopoid copepods and Bosmina spp. generally were rare. Thus, enclosure zooplankton communities differed from the lake in that they supported more Daphnia spp. and fewer cyclopoid copepods.

In enclosures, mean treatment densities, based on recovery of gizzard shad from enclosures, were $12(N=4), 31(N=4), 43(N=4)$, and $41(N=$ 4) fish $/ \mathrm{m}^{3}$ (Table 1). Survival (mean $\pm \mathrm{SE}$ ) during June 16-July 21, 1992, pooled across treatments and corrected for fish known to be in enclosures before our manipulation, was $88.7 \pm 6.6 \%$.

After the addition of gizzard shad, zooplankton abundance differed among treatments (Figure 1B; Table 2); zooplankton were less abundant in all enclosures to which we added gizzard shad than in enclosures without added gizzard shad (Tukey's multiple comparisons, $P<0.05$ ). Zooplankton declined through time in all treatments, but declined more rapidly when gizzard shad were added (Figure 1B; Table 2). Both calanoid copepods and Daphnia spp. declined substantially.

Dynamics of zooplankton biomass (Table 2) and production (Table 2; Figure 2A) mimicked zooplankton density patterns in response to gizzard shad. Crustacean zooplankton size declined through time, but did not differ across gizzard shad densities (Figure 1C; Table 2).

Edible phytoplankton biovolume (primarily Scenedesmus spp., Cryptomonas spp., Euglena spp., and Cyclotella spp.) differed among treatments and through time (Figure 1D; Table 3); edible phytoplankton biovolume was greatest in the treatment in which we added the most gizzard shad (Tukey's multiple comparisons, $P<0.05$ ). Inedible phytoplankton (primarily Oscillatoria spp., Synedra spp., Cosmarium spp., and Closterium spp.) did not differ among treatments, although biovolume varied slightly through time (Table 3 ).

Because gizzard shad invaded all Clark Lake enclosures and we could not maintain consistent gizzard shad densities within treatments, we also analyzed these results by regression. Zooplankton density was inversely related to gizzard shad density beginning the second week following gizzard shad addition. By July 21 , the regression explained $83 \%$ of the existing variance in zooplankton density across enclosures $\log _{e}$ [zooplankton $+1]=7.49-1.69 \cdot \log _{e}[$ gizzard shad +1$]$; Figure $3 \mathrm{~A}$ ).

Kokosing Lake.-Zooplankton did not peak in Kokosing Lake during spring and never exceeded 45 individuals/L (Figure 4A), whereas zooplankton peaks of more than 500/L occurred in 11 of 12 enclosures. Dominant zooplankton in the lake were Diaphanosoma spp., cyclopoid copepods, calanoid copepods, and copepod nauplii. Larval gizzard shad first appeared on May 16 and reached a peak density of $15 / \mathrm{m}^{3}$ on May 23, with a secondary peak on June 5 (Figure 4A). By June 12, 

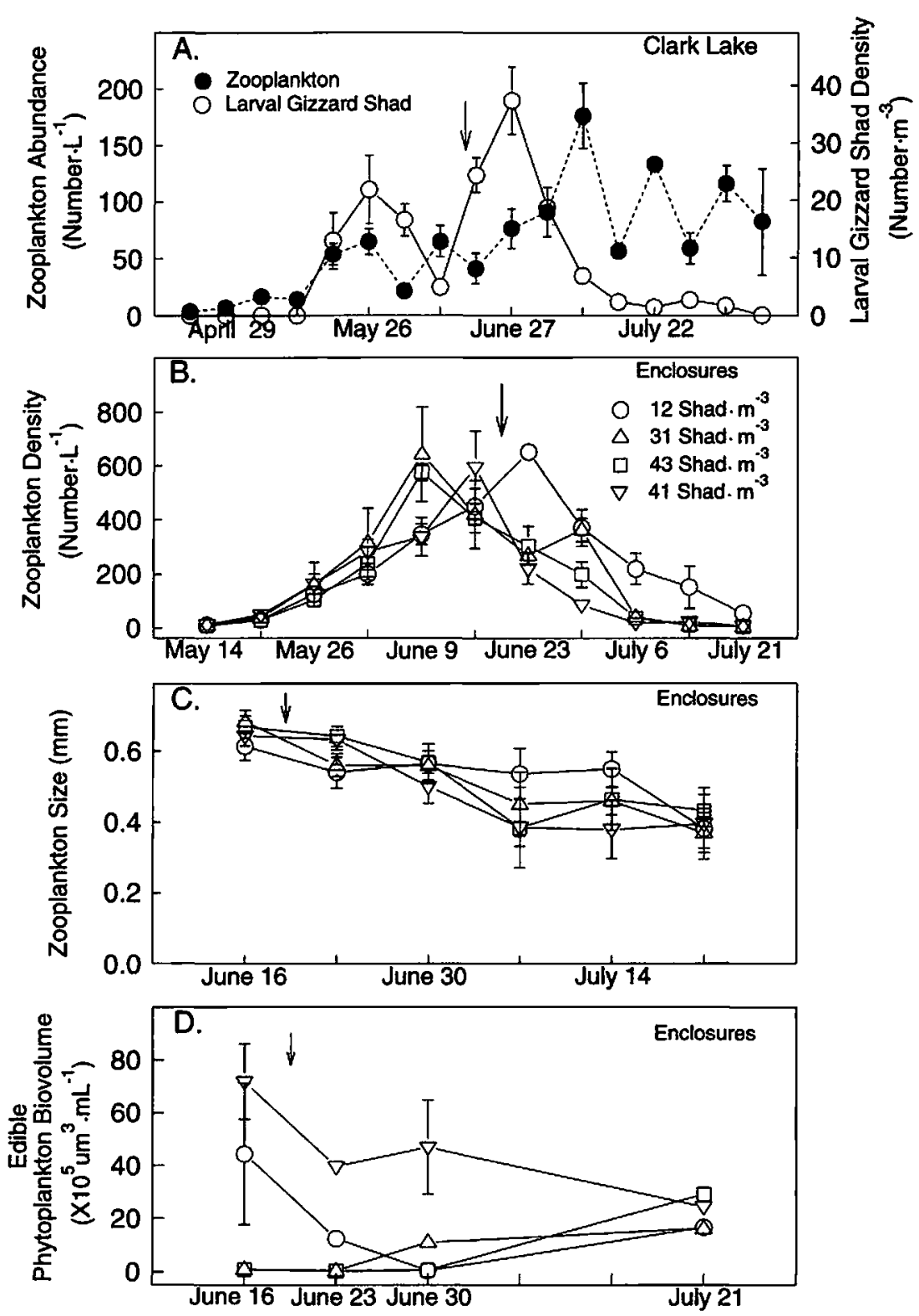

FIGURE 1.-Means ( \pm SE) of $(A)$ crustacean zooplankton and larval gizzard shad abundance in Clark Lake, April 23-September 2, 1992; (B) crustacean zooplankton abundance in enclosure treatments, May 14-July 21, 1992; (C) crustacean zooplankton size; and (D) edible phytoplankton biovolume $\left(\mu \mathrm{m}^{3} / \mathrm{mL}\right)$, June 16-July 21 , 1992. Arrows indicate the dates gizzard shad were added to enclosures. Abscissa scale differs among panels.

most larval gizzard shad had metamorphosed into juveniles ( $>25 \mathrm{~mm}$ TL) that could avoid our collection gear.

Zooplankton density in Kokosing Lake enclosure treatments initially was less than $5 / \mathrm{L}$ during May 8-22 and increased to more than 500/L during June 5-June 12, just before gizzard shad were added (Figure 4B). Bosmina spp., copepod nauplii, and cyclopoid copepods were dominant; calanoid copepods and Daphnia spp. generally were rare. Bosmina spp. were a greater proportion of the zooplankton community in enclosures, whereas calanoid copepods were more abundant in the lake.

Final gizzard shad treatment densities, based on recovery from intact enclosures, were $0(N=2)$, $4(N=1), 9(N=2)$, and $17(N=1) \mathrm{fish} / \mathrm{m}^{3}$. 
TABLE 2.-Summary of results of split-plot repeatedmeasures analysis of variance for $\log _{e}$-transformed responses of zooplankton density, biomass, and production, and the response of zooplankton size to increased age-0 gizzard shad abundance in enclosures in Kokosing, Clark, and Knox lakes, Ohio. May-July, 1991 and 1992.

\begin{tabular}{|c|c|c|c|c|}
\hline Response variable & df & $\begin{array}{l}\text { Mean } \\
\text { square }\end{array}$ & $F$ & $P$ \\
\hline \multicolumn{5}{|c|}{ Clark Lake } \\
\hline $\begin{array}{l}\log _{e} \text { (density) } \\
\text { Time } \\
\text { Time } \times \text { treatment }\end{array}$ & $\begin{array}{r}3 \\
5 \\
15\end{array}$ & $\begin{array}{r}10.58 \\
45.16 \\
1.33\end{array}$ & $\begin{array}{r}11.83 \\
91.96 \\
2.71\end{array}$ & $\begin{array}{l}0.0018 \\
0.0001 \\
0.0033\end{array}$ \\
\hline $\begin{array}{l}\log _{e} \text { (biomass) } \\
\text { Time } \\
\text { Time } \times \text { treatment }\end{array}$ & $\begin{array}{r}3 \\
5 \\
15\end{array}$ & $\begin{array}{r}14.92 \\
65.64 \\
2.00\end{array}$ & $\begin{array}{r}8.49 \\
88.63 \\
2.70\end{array}$ & $\begin{array}{l}0.0054 \\
0.0001 \\
0.0034\end{array}$ \\
\hline $\begin{array}{l}\log _{e} \text { (production) } \\
\text { Time } \\
\text { Time } \times \text { treatment }\end{array}$ & $\begin{array}{r}3 \\
5 \\
15\end{array}$ & $\begin{array}{r}11.62 \\
55.81 \\
1.82\end{array}$ & $\begin{array}{r}10.76 \\
85.03 \\
2.78\end{array}$ & $\begin{array}{l}0.0025 \\
0.0001 \\
0.0026\end{array}$ \\
\hline $\begin{array}{l}\text { Size } \\
\text { Time } \\
\text { Time } \times \text { treatment }\end{array}$ & $\begin{array}{r}3 \\
5 \\
15\end{array}$ & $\begin{array}{l}0.08 \\
0.15 \\
0.01\end{array}$ & $\begin{array}{r}0.24 \\
15.92 \\
1.10\end{array}$ & $\begin{array}{l}0.87 \\
0.0001 \\
0.38\end{array}$ \\
\hline \multicolumn{5}{|c|}{ Kokosing Lake } \\
\hline $\begin{array}{l}\log _{e} \text { (density) } \\
\text { Time } \\
\text { Time } \times \text { treatment }\end{array}$ & $\begin{array}{r}3 \\
4 \\
12\end{array}$ & $\begin{array}{r}6.13 \\
14.39 \\
1.60\end{array}$ & $\begin{array}{r}5.22 \\
21.38 \\
2.38\end{array}$ & $\begin{array}{l}0.053 \\
0.0001 \\
0.03\end{array}$ \\
\hline $\begin{array}{l}\log _{e} \text { (biomass) } \\
\text { Time } \\
\text { Time } \times \text { treatment }\end{array}$ & $\begin{array}{r}3 \\
4 \\
12\end{array}$ & $\begin{array}{r}8.93 \\
18.27 \\
2.12\end{array}$ & $\begin{array}{r}7.33 \\
18.05 \\
2.10\end{array}$ & $\begin{array}{l}0.028 \\
0.0001 \\
0.054\end{array}$ \\
\hline $\begin{array}{l}\log _{e} \text { (production) } \\
\text { Time } \\
\text { Time } \times \text { treatment }\end{array}$ & $\begin{array}{r}3 \\
4 \\
12\end{array}$ & $\begin{array}{l}5.90 \\
7.97 \\
1.98\end{array}$ & $\begin{array}{r}10.04 \\
8.03 \\
1.99\end{array}$ & $\begin{array}{l}0.015 \\
0.0002 \\
0.067\end{array}$ \\
\hline $\begin{array}{l}\text { Size } \\
\text { Time } \\
\text { Time } \times \text { treatment }\end{array}$ & $\begin{array}{c}3 \\
4 \\
12\end{array}$ & $\begin{array}{l}0.002 \\
0.037 \\
0.004\end{array}$ & $\begin{array}{l}0.55 \\
8.96 \\
0.99\end{array}$ & $\begin{array}{l}0.67 \\
0.0001 \\
0.49\end{array}$ \\
\hline \multicolumn{5}{|c|}{ Knox Lake } \\
\hline $\begin{array}{l}\log _{e} \text { (density) } \\
\text { Time } \\
\text { Time } \times \text { treatment }\end{array}$ & $\begin{array}{r}3 \\
5 \\
15\end{array}$ & $\begin{array}{r}19.49 \\
100.11 \\
3.99\end{array}$ & $\begin{array}{r}38.46 \\
109.20 \\
4.35\end{array}$ & $\begin{array}{l}0.0001 \\
0.0001 \\
0.0001\end{array}$ \\
\hline $\begin{array}{l}\log _{e} \text { (biomass) } \\
\text { Time } \\
\text { Time } \times \text { treatment }\end{array}$ & $\begin{array}{r}3 \\
5 \\
15\end{array}$ & $\begin{array}{r}32.92 \\
97.41 \\
6.36\end{array}$ & $\begin{array}{r}58.96 \\
58.14 \\
3.79\end{array}$ & $\begin{array}{l}0.0001 \\
0.0001 \\
0.0005\end{array}$ \\
\hline $\begin{array}{l}\log _{e} \text { (production) } \\
\text { Time } \\
\text { Time } \times \text { treatment }\end{array}$ & $\begin{array}{r}3 \\
5 \\
15\end{array}$ & $\begin{array}{r}26.55 \\
78.16 \\
4.76\end{array}$ & $\begin{array}{r}58.05 \\
53.51 \\
3.26\end{array}$ & $\begin{array}{l}0.0001 \\
0.0001 \\
0.0019\end{array}$ \\
\hline $\begin{array}{l}\text { Size } \\
\text { Time } \\
\text { Time } \times \text { treatment }\end{array}$ & $\begin{array}{r}3 \\
5 \\
15\end{array}$ & $\begin{array}{l}0.08 \\
0.08 \\
0.02\end{array}$ & $\begin{array}{l}3.42 \\
6.44 \\
1.50\end{array}$ & $\begin{array}{l}0.066 \\
0.0003 \\
0.16\end{array}$ \\
\hline
\end{tabular}

Survival during June 13-July 26, 1991, pooled across treatments, was $63.9 \pm 3.6 \%$.

After juvenile gizzard shad addition, zooplankton differed marginally among treatments (Figure 4B; Table 2). Fewer zooplankton occurred with 20 gizzard $\mathrm{shad} / \mathrm{m}^{3}$ than in fishless enclosures (Tukey's multiple comparisons, $P<0.05$ ). Although zooplankton abundance declined through time in all treatments, it declined more rapidly in the pres- ence of gizzard shad (Figure 4B; Table 2). Calanoid and cyclopoid copepods, as well as Daphnia spp., were the taxa most strongly reduced by gizzard shad. Regression analysis of zooplankton remaining versus gizzard shad recovered from enclosures revealed a negative relation beginning 2 weeks after gizzard shad addition. On July 10 , gizzard shad abundance explained $97 \%$ of the variability in zooplankton density across enclosures $\left(\log _{e}[\right.$ zooplankton +1$]=6.12-1.28 \cdot \log _{e}$ [gizzard shad +1 ]; Figure 3B).

Zooplankton biomass differed among Kokosing Lake treatments (Table 2), being greatest in fishless enclosures (Tukey's multiple comparisons, $P$ $<0.05$ ). Although biomass declined through time, the rate of decline differed only slightly among treatments (Table 2). Zooplankton production declined in all treatments containing gizzard shad (Table 2; Figure 2B; Tukey's multiple comparisons, $P<0.05$ ) and through time (Table 2). Zooplankton size did not differ among treatments, but varied through time (Figure $4 \mathrm{C}$; Table 2).

Phytoplankton responses were not as dramatic in Kokosing Lake as in Clark Lake. Neither edible (primarily Scenedesmus spp. and Euglena spp.) nor inedible (primarily Cosmarium spp., Mougeotia spp., and Synedra spp.) phytoplankton biovolume differed among treatments (Figure 4D; Table 3). However, both fractions varied through time (Table 3).

Knox Lake.-Zooplankton were abundant in Knox Lake, peaking at more than 1,100 organisms/ L on May 27. Zooplankton numbers remained above $300 / \mathrm{L}$ through June 25 , after which they crashed (Figure 5A). Larval gizzard shad first appeared on May 20; their abundance peaked on June 3 (Figure 5A), and larvae were present through June 24. Peak larval gizzard shad abundance closely mimicked the timing of the zooplankton peak.

Zooplankton density in Knox Lake enclosures before gizzard shad were added mimicked lakewide trends. Initially, abundance was less than 76/ $\mathrm{L}$ during May 13-20; abundance increased to more than 260/L during May 21-28 (Figure 5B) and remained more than $300 / \mathrm{L}$ during May 29-June 18 , when gizzard shad were added to enclosures. Bosmina spp. were dominant; calanoid copepods, copepod nauplii, Daphnia spp., and Chydorus spp. were common but less abundant.

Final treatment densities, based on recovery of gizzard shad from enclosures, were $0(N=3), 5$ $(N=4), 7(N=4)$, and $11(N=4) \mathrm{fish} / \mathrm{m}^{3}$. Survival during June 18 -July 15,1992 , pooled across treatments and corrected for fish known to be in 

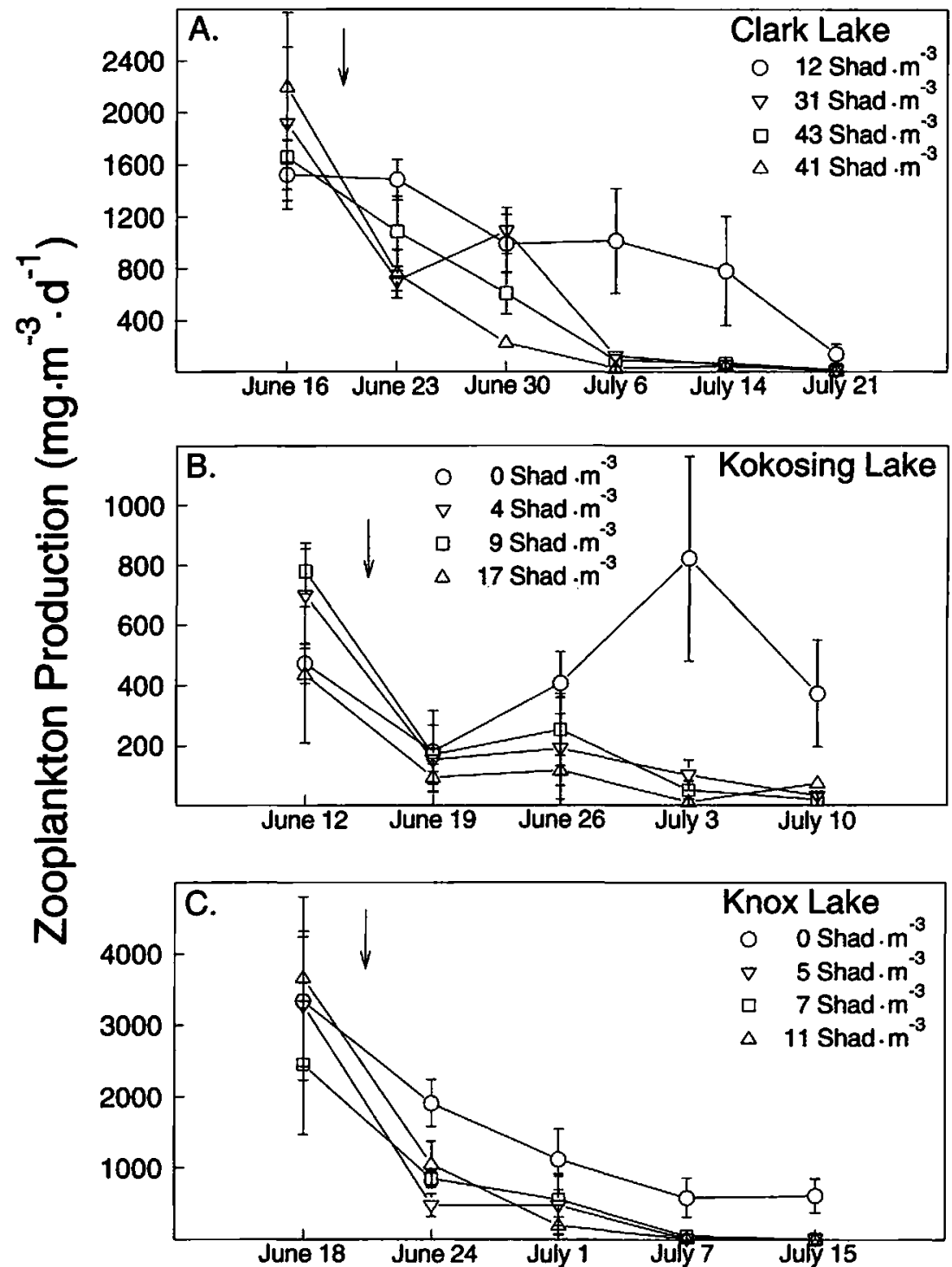

Figure 2.-Means ( $\pm S E$ ) of crustacean zooplankton production in enclosure treatments at (A) Clark Lake, June 16-July 21, 1992; (B) Kokosing Lake, June 12-July 10, 1991; and (C) Knox Lake, June 18-July 15, 1992. Arrows indicate the dates gizzard shad were added to enclosures. Abscissa scale differs among panels.

enclosures before our manipulation, was $74.3 \pm$ $8.0 \%$.

Zooplankton abundance differed among treatments (Figure 5B; Table 2); fewer zooplankton were in enclosures containing gizzard shad ( $\mathrm{Tu}$ key's multiple comparisons, $P<0.05$ ). Although zooplankton abundance declined through time in all treatments, it declined more rapidly in the presence of gizzard shad (Figure 5B; Table 2). Bosmina spp. and calanoid copepod populations were most strongly affected by gizzard shad. Regression analysis revealed that gizzard shad abundance explained $74 \%$ of the existing variance in zooplankton remaining in enclosures on July 15 ( $\log _{e}$ [zooplankton +1$]=3.49-1.94 \cdot \log _{e}$ [gizzard shad + 1]; Figure 3C).

Dynamics of zooplankton biomass (Table 2) and production (Figure 2C; Table 2) followed zooplankton density patterns. Mean zooplankton size varied with time and differed slightly among treat- 
TABLE 3.-Summary of results of split-plot repeatedmeasures analysis of variance for $\log _{e}$-transformed responses of phytoplankton biovolume to increased age-0 gizzard shad abundance in enclosures in Clark, Kokosing, and Knox lakes, Ohio, June-July, 1991 and 1992.

\begin{tabular}{|c|c|c|c|c|}
\hline Response variable & df & $\begin{array}{l}\text { Mean } \\
\text { Square }\end{array}$ & $\boldsymbol{F}$ & $P$ \\
\hline \multicolumn{5}{|c|}{ Clark Lake } \\
\hline Edible biovolume & 3 & 9.35 & 8.12 & 0.006 \\
\hline Subplot error & 9 & 1.15 & & \\
\hline Time & 3 & 4.99 & 5.39 & 0.004 \\
\hline Time $\times$ treatment & 9 & 1.41 & 1.53 & 0.18 \\
\hline Main plot error & 34 & 0.93 & & \\
\hline Inedible biovolume & 3 & 3.03 & 2.85 & 0.10 \\
\hline Subplot error & 9 & 1.06 & & \\
\hline Time & 3 & 3.38 & 2.67 & 0.06 \\
\hline Time $\times$ treatment & 9 & 1.64 & 1.30 & 0.27 \\
\hline Main plot error & 34 & 1.26 & & \\
\hline \multicolumn{5}{|c|}{ Kokosing Lake } \\
\hline Edible biovolume & 3 & 0.93 & 0.94 & 0.49 \\
\hline Sub-plot error & 5 & 0.98 & & \\
\hline Time & 3 & 7.11 & 18.73 & 0.0001 \\
\hline Time $\times$ treatment & 9 & 0.74 & 1.95 & 0.10 \\
\hline Main plot error & 20 & 0.38 & & \\
\hline Inedible biovolume & 3 & 0.18 & 0.26 & 0.85 \\
\hline Subplot error & 5 & 0.72 & & \\
\hline Time & 3 & 3.96 & 3.98 & 0.02 \\
\hline Time $\times$ treatment & 9 & 0.88 & 0.88 & 0.56 \\
\hline Main plot error & 20 & 0.99 & & \\
\hline \multicolumn{5}{|c|}{ Knox Lake } \\
\hline Edible biovolume & 3 & 0.16 & 0.09 & 0.96 \\
\hline Subplot error & 9 & 1.73 & & \\
\hline Time & 3 & 6.60 & 20.45 & 0.0001 \\
\hline Time $\times$ treatment & 9 & 0.39 & 1.20 & 0.33 \\
\hline Main plot error & 35 & 0.32 & & \\
\hline Inedible biovolume & 3 & 2.86 & 0.28 & 0.84 \\
\hline Subplot error & 9 & 10.11 & & \\
\hline Time & 3 & 6.68 & 1.72 & 0.18 \\
\hline Time $\times$ treatment & 9 & 7.44 & 1.92 & 0.08 \\
\hline Main plot error & 35 & 3.88 & & \\
\hline
\end{tabular}

ments, with zooplankton size in fishless enclosures tending to be larger (Figure 5C; Table 2).

Neither edible (Cymbella spp. and Scenedesmus spp.) nor inedible (Spirogyra spp. and Mougeotia spp.) phytoplankton biovolume differed among treatments (Figure 5D; Table 3 ). The edible fraction varied through time; the inedible fraction did not (Figure 5D; Table 3).

\section{Understanding Zooplankton Productivity and Persistence}

Final zooplankton density in enclosures was negatively related to gizzard shad density and positively related to zooplankton production. We generated a response surface using data from 36 enclosures across our three lakes to interpolate across the range of our data with the SigmaPlot graphics package (Figure 6). Regression analysis with lake

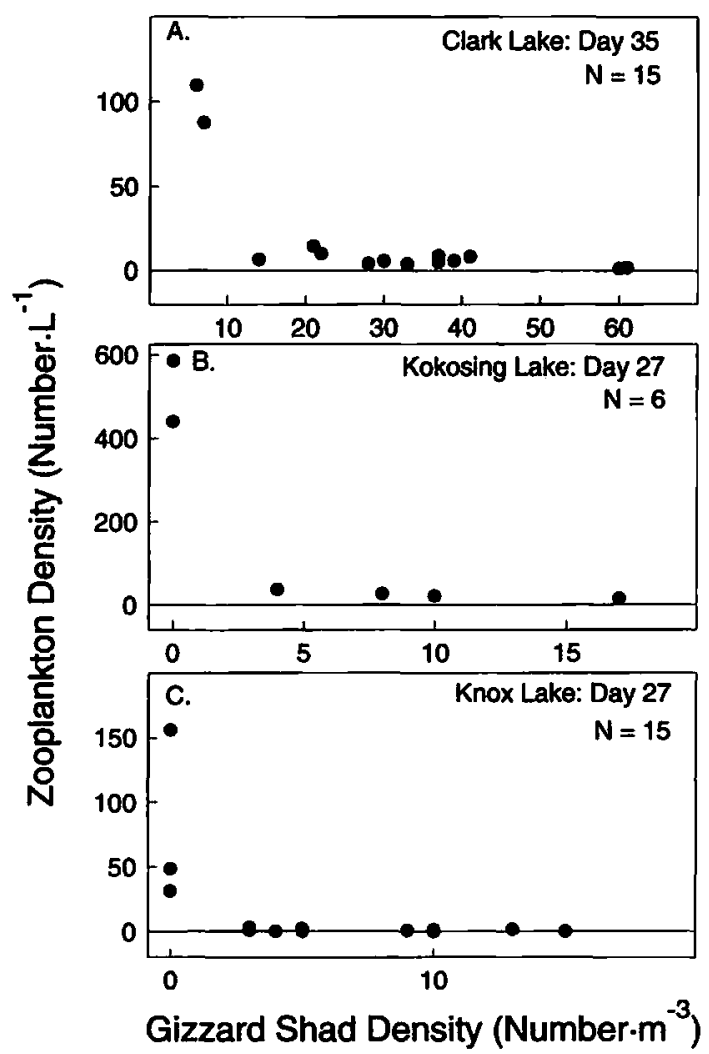

FIGURE 3.-Plots of the relation between zooplankton density and gizzard shad density in enclosures on the last day of experiments: (A) after $35 \mathrm{~d}$ in Clark Lake, on July 21, 1992; (B) after $27 \mathrm{~d}$ in Kokosing Lake, on July 10, 1991; and (C) after $27 \mathrm{~d}$ in Knox Lake, on July 15, 1992. See Table 4 for the specific regression relationships.

as an indicator variable explained more than $94 \%$ of the observed variation in zooplankton remaining in enclosures by accounting for gizzard shad density, zooplankton production, and lake-to-lake differences (Table 4). This analysis revealed that final zooplankton abundance was influenced negatively by gizzard shad density and positively by crustacean zooplankton production (Figure 6). Although zooplankton abundance and zooplankton production may be correlated, this analysis describes those conditions necessary for zooplankton persistence. Adding phytoplankton concentration and interaction terms to this model provided no additional explanatory power to the observed pattern of zooplankton abundance.

We then assessed these lake-to-lake differences, and discovered that Clark and Kokosing lakes were similar, but differed from Knox Lake (Table 4). In 

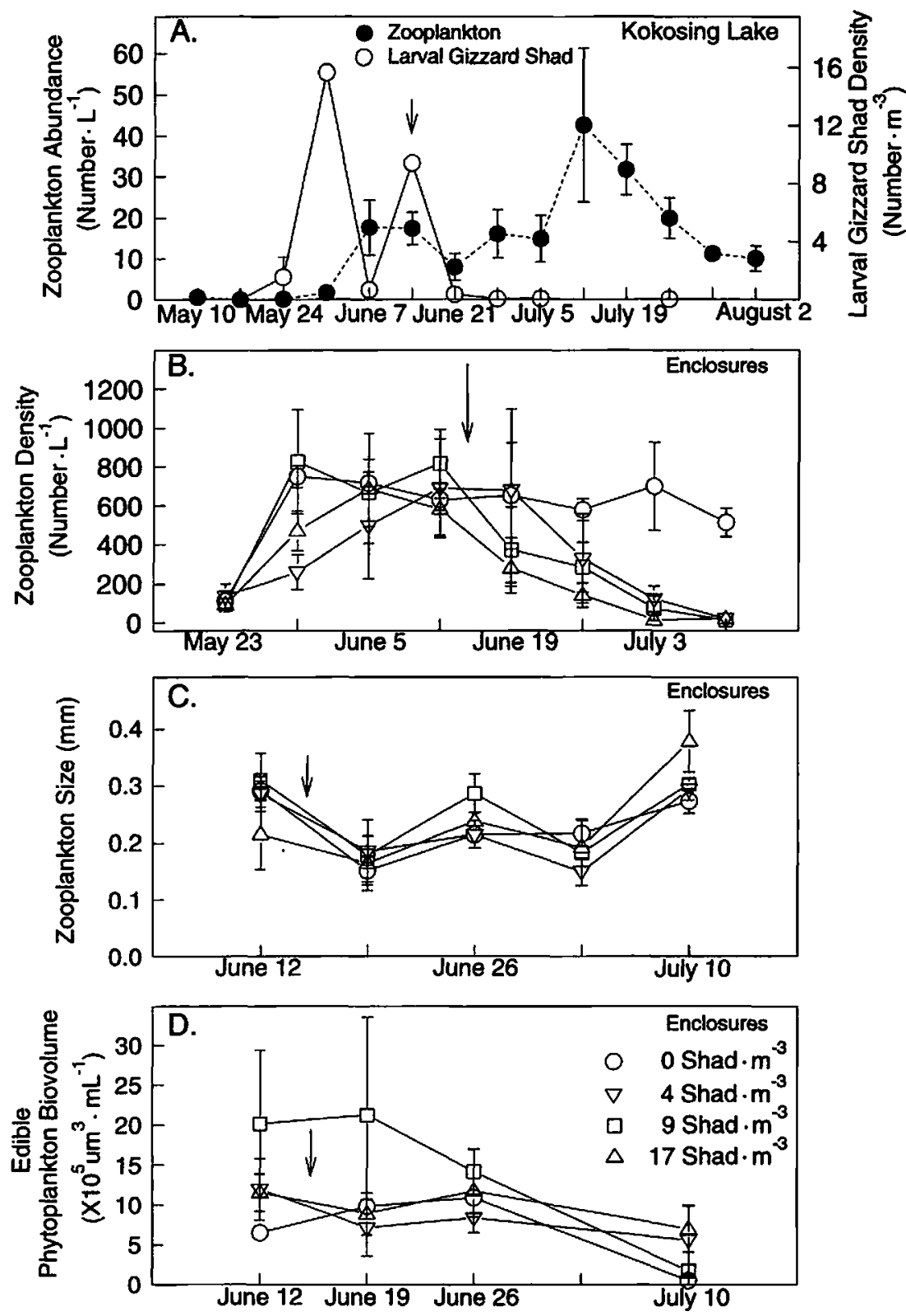

FIGURE 4.-Means ( \pm SE) of (A) crustacean zooplankton and larval gizzard shad abundance in Kokosing Lake, May 10-August 2, 1991; (B) crustacean zooplankton abundance in enclosure treatments, May 23-July 10, 1991; (C) crustacean zooplankton size; (D) edible phytoplankton biovolume $\left(\mu^{3} / \mathrm{mL}\right)$, June $12-J u l y ~ 10,1991$. Arrows indicate the dates gizzard shad were added to enclosures. Abscissa scale differs among panels.

Knox Lake, gizzard shad abundance was less strongly correlated with final zooplankton abundance than was zooplankton production. In Clark Lake, gizzard shad and zooplankton production affected final zooplankton abundance similarly. In Kokosing Lake, gizzard shad density controlled zooplankton dynamics.
Peak zooplankton densities exceeding 800/L occurred in several enclosures in each lake before gizzard shad were added, despite differences in productivity among lakes. These peak zooplankton densities responded quite differently to our range of gizzard shad consumption. To explain why zooplankton remained more abundant in Clark Lake 

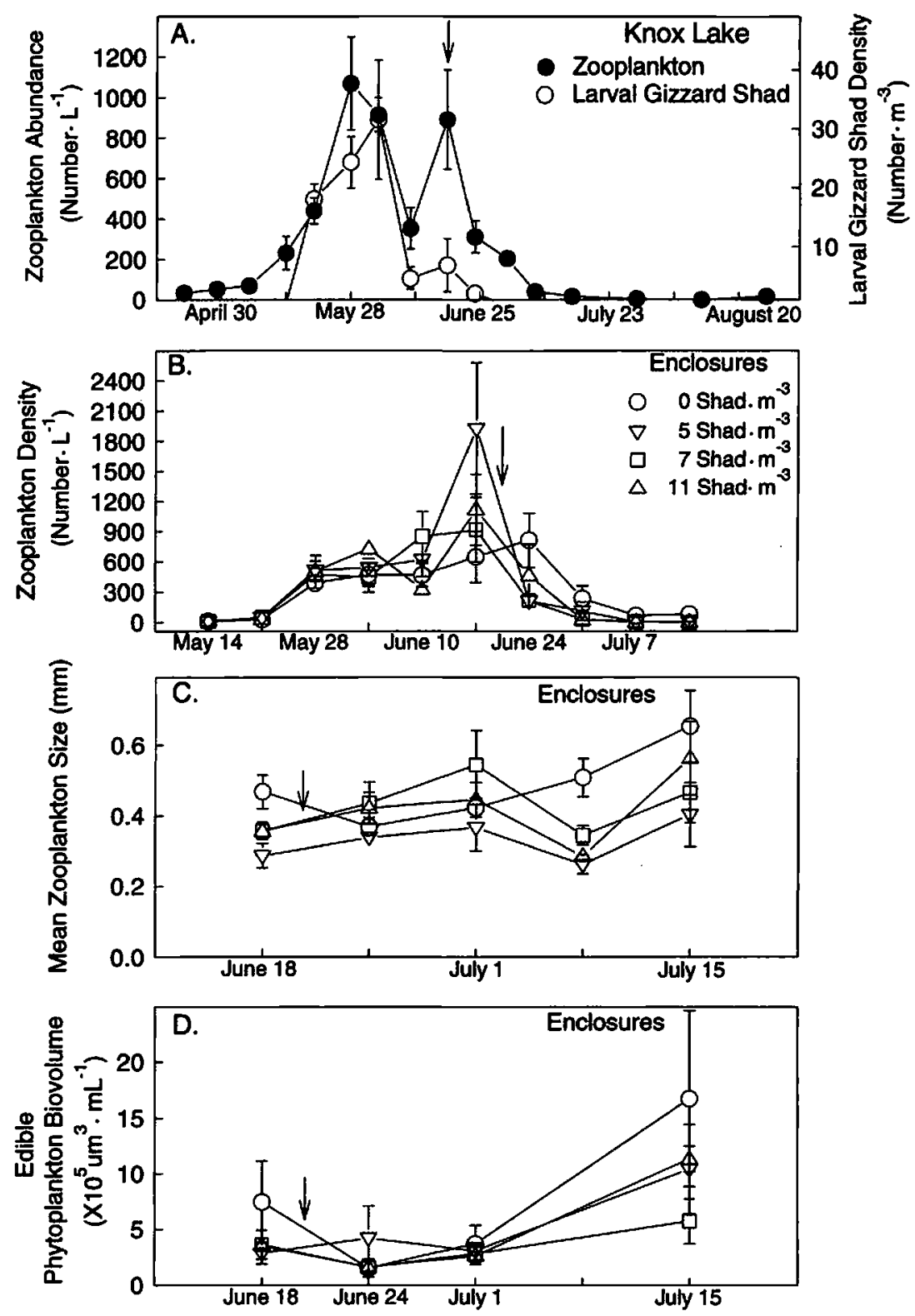

Figure 5.-Means ( \pm SE) of (A) crustacean zooplankton and larval gizzard shad abundance in Knox Lake, April 23-August 27, 1992; (B) crustacean zooplankton abundance in enclosure treatments, May 14-July 15, 1992; (C) crustacean zooplankton size; and (D) edible phytoplankton biovolume $\left(\mu \mathrm{m}^{3} / \mathrm{mL}\right)$, June 18-July 15,1992 . Arrows indicate the dates gizzard shad were added to enclosures. Abscissa scale differs among panels.

enclosures than in enclosures from other lakes, we examined final zooplankton density in enclosures. If final zooplankton density differed when final gizzard shad density was similar across enclosures, we might expect nutrient-related factors to be responsible for the observed differences. We only compared enclosures containing 3-12 gizzard $\mathrm{shad} / \mathrm{m}^{3}$, densities common to all experiments. In this subset of enclosures, mean gizzard shad density was similar across enclosures (Clark, 6.5; Kokosing, 7.3; Knox, 5.9). Zooplankton density differed across enclosures (ANOVA; $F=261.66$; df $=2,12 ; P<0.0001)$; most zooplankton remained in Clark Lake (mean, 98.6/L), some remained in 


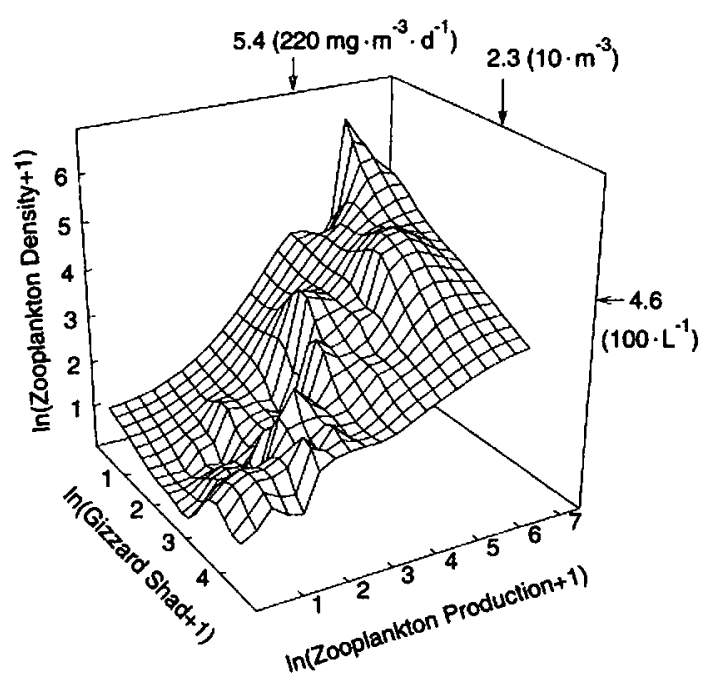

FIGURE 6.-Response surface of zooplankton remaining in enclosures at the end of each experiment versus the number of gizzard shad retrieved from each enclosure and final zooplankton production for Kokosing, Clark, and Knox lakes (In $=\log _{e}$ ). Arrows and associated numbers highlight the critical values of zooplankton production and gizzard shad density necessary for zooplankton to persist at abundances of more than 100/L.

Kokosing Lake (mean, 28.0/L), and few remained in Knox Lake (mean, 1.0/L). These results suggest nutrient or bottom-up influences were important.

To assess how bottom-up processes influenced zooplankton in the face of planktivore consumption, we examined the seasonal ratios of zooplankton births to deaths (ratios: 0.88 in Clark Lake; 0.35 in Knox Lake; 0.28 in Kokosing Lake). These ratios differed among lakes (ANOVA; $F=8.29$; df $=2,167 ; P=0.0004$ ) and were greatest for Clark Lake enclosures (Tukey's multiple comparisons, $\boldsymbol{P}<0.05$ ), suggesting that conditions for zooplankton were more favorable in Clark Lake enclosures.

We also examined the seasonal ratios of edible: inedible phytoplankton biovolume (E:I) in enclosures across lakes to assess food quality for zooplankton. These ratios differed among lake and enclosure combinations (ANOVA; $F=80.00$; df $=2,165 ; P<0.0001$ ) and were greatest in Clark Lake enclosures ( $E: I, 3.9)$, intermediate in Kokosing enclosures (1.6), and lowest in Knox enclosures (0.3), suggesting that food quality, in addition to gizzard shad predation, probably determined mortality of zooplankton across lakes.

\section{Discussion}

Age-0 gizzard shad (23-90 mm TL) eliminated crustacean zooplankton from enclosures within 2-
3 weeks in all experiments. Although we varied gizzard shad density more than 15-fold across all treatments, we found few differences among treatments containing gizzard shad. Regardless of productivity, zooplankton was nearly eliminated when there were more than 12 gizzard shad $/ \mathrm{m}^{3}$. Zooplankton persisted at more than $100 / \mathrm{L}$, the density required for larval fish survival (Werner and Blaxter 1980; Eldridge et al. 1981; Li and Mathias 1982), only when daily zooplankton production exceeded $220 \mathrm{mg} / \mathrm{m}^{3}$ and gizzard shad abundance was less than $10 / \mathrm{m}^{3}$. Size-selective predation by gizzard shad on zooplankton did not occur. Topdown effects cascaded to phytoplankton only in those enclosures with Daphnia spp. densities initially greater than $40 / \mathrm{L}$ and abundant edible algae.

Enclosure results mimicked the lakewide zooplankton trends only in Knox Lake, which suggested that zooplankton in Knox Lake persisted in the face of larval gizzard shad consumption. However, as gizzard shad grew longer than $25 \mathrm{~mm}$, the consumptive demand of gizzard shad probably overwhelmed the production of zooplankton, causing its collapse (Dettmers and Stein 1992). The rate and timing of this decline was quite similar to the timing of the zooplankton collapse in enclosures after the addition of 23-mm gizzard shad.

In Clark and Kokosing lakes, zooplankton density remained low relative to densities observed in enclosures before gizzard shad were added. Perhaps this difference resulted from additional predation pressure on zooplankton exerted by abundant adult gizzard shad and other planktivores that increased consumptive demand on zooplankton in spring. We have no direct evidence that populations of adult gizzard shad or other planktivores were abundant in Clark and Kokosing lakes but rare in Knox Lake. However, in Lake Mendota, Wisconsin, abundant populations of cisco Coregonus artedi could account for the observed Daphnia spp. mortality during April-September 1987 , except for 2-3 weeks in late May-early June (Luecke et al. 1992). Thus, it is possible that adult fishes maintained zooplankton at low levels by predation in our reservoirs. Given that our enclosures protected crustacean zooplankton from all predation sources, we believe our test with enclosures strengthens our conclusion that age- 0 gizzard shad can eliminate reservoir zooplankton. This extreme reduction of zooplankton contrasts with results from northern temperate lakes. For example, zooplankton dramatically increased in Lake St. George in Ontario, following a winterkill that eliminated piscivores (McQueen et al. 1989). A 
TABLE 4.-Regressions predicting zooplankton density remaining in enclosures, for given gizzard shad density and zooplankton production levels, across all enclosures from all reservoirs, and for each reservoir. The regression model

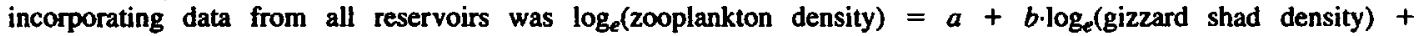
$c \cdot \log _{e}(z o o p l a n k t o n$ production $)+d$-reservoir. Partial regressions for gizzard shad density and zooplankton production are presented for each reservoir. Regressions for Clark and Kokosing lakes were similar $(P=0.19)$, but both differed from the relationship in Knox Lake enclosures $(P<0.0001)$.

\begin{tabular}{|c|c|c|c|c|c|c|c|}
\hline \multirow[b]{2}{*}{ Dependent variable } & \multicolumn{3}{|c|}{ Regression coefficients: } & \multirow[b]{2}{*}{$F$} & \multirow[b]{2}{*}{$P$} & \multirow[b]{2}{*}{$R^{2}$} & \multirow[b]{2}{*}{$r^{2}$} \\
\hline & $a$ & $b$ & $c$ & & & & \\
\hline \multicolumn{8}{|c|}{ Clark Lake $(N=15)$} \\
\hline $\begin{array}{l}\text { Gizzard shad density and } \\
\text { zooplankton production } \\
\text { Gizzard shad density } \\
\text { Zooplankton production }\end{array}$ & $\begin{array}{l}4.18 \\
7.91 \\
0.32\end{array}$ & $\begin{array}{l}-0.96 \\
-1.79\end{array}$ & $\begin{array}{l}0.42 \\
0.71\end{array}$ & $\begin{array}{r}185.20 \\
60.62 \\
70.59\end{array}$ & $\begin{array}{l}<0.0001 \\
<0.0001 \\
<0.0001\end{array}$ & 0.92 & $\begin{array}{l}0.81 \\
0.83\end{array}$ \\
\hline \multicolumn{8}{|c|}{ Kokosing Lake $(N=6)$} \\
\hline $\begin{array}{l}\text { Gizzard shad density and } \\
\text { zooplankton production } \\
\text { Gizzard shad density } \\
\text { Zooplankton production }\end{array}$ & $\begin{array}{r}4.09 \\
6.12 \\
-1.67\end{array}$ & $\begin{array}{l}-1.00 \\
-1.28\end{array}$ & $\begin{array}{l}0.33 \\
1.21\end{array}$ & $\begin{array}{r}121.23 \\
136.85 \\
20.21\end{array}$ & $\begin{array}{c}0.001 \\
<0.0001 \\
0.01\end{array}$ & 0.98 & $\begin{array}{l}0.97 \\
0.79\end{array}$ \\
\hline \multicolumn{8}{|c|}{ Knox Lake $(N=15)$} \\
\hline $\begin{array}{l}\text { Gizzard shad density and } \\
\text { zooplankton production } \\
\text { Gizzard shad density } \\
\text { Zooplankton production }\end{array}$ & $\begin{array}{r}-1.06 \\
3.49 \\
-1.70\end{array}$ & $\begin{array}{l}-0.28 \\
-1.94\end{array}$ & $\begin{array}{l}0.84 \\
0.93\end{array}$ & $\begin{array}{r}123.91 \\
24.40 \\
239.93\end{array}$ & $\begin{array}{l}<0.0001 \\
<0.0001 \\
<0.0001\end{array}$ & 0.95 & $\begin{array}{l}0.63 \\
0.95\end{array}$ \\
\hline \multicolumn{8}{|c|}{ All reservoirs $(N=36)$} \\
\hline $\begin{array}{l}\text { Gizzard shad density and } \\
\text { zooplankton production }\end{array}$ & 3.79 & -0.63 & 0.72 & 185.20 & $<0.0001$ & 0.94 & \\
\hline
\end{tabular}

The equation for all reservoirs includes the coefficient $d$ (see table legend), calculated to be -1.31 .

large year-class of planktivores subsequently reduced zooplankton biomass, but zooplankton were still more abundant in Lake St. George (biomass was reduced to about $1,500 \mathrm{mg} / \mathrm{m}^{3}$ ) than in our study (biomass was reduced to less than $50 \mathrm{mg}$ / $\mathrm{m}^{3}$ ). Perhaps the biomass of planktivores used in our study equaled or exceeded that in Lake St. George. If so, our planktivores probably exerted a greater consumptive demand on zooplankton, forcing them to very low levels. Gizzard shad probably maintain their high biomass in reservoirs because they can feed successfully on detritus, which allows them to persist in the face of low zooplankton resources.

However, planktivore biomass (estimated biomass of cisco and yellow perch, $200 \mathrm{~kg} / \mathrm{ha}$ ) in Lake Mendota before the 1987 cisco die-off equaled or exceeded final gizzard shad biomass in 25 of 44 enclosures (Rudstam et al. 1992). Yet Lake Mendota zooplankton was more abundant than in our study. Thus, planktivore biomass does not completely explain the differences in zooplankton abundance observed between natural lakes and our reservoirs.

Enclosure effects also could have artificially increased the impact of gizzard shad on zooplankton because detritus was unavailable to gizzard shad.
We think this is unlikely because zooplankton abundance in our reservoirs either remained low or declined at rates similar to rates in our enclosures, and extensive periphyton growth occurred in the enclosures, providing gizzard shad with an alternative food resource.

Gizzard shad detritivory also may explain poor zooplankton persistence in our enclosures. Given their capacity to switch food sources from zooplankton to phytoplankton and detritus (Miller 1960; Bodola 1966), gizzard shad are more weakly linked to zooplankton than northern planktivores (even those that rely partially on benthos), because detritus in most Ohio reservoirs is essentially unlimited. Thus, gizzard shad eliminate crustacean zooplankton and then simply switch to detritus to maintain high population biomass.

Zooplankton and phytoplankton did not seem linked in our age- 0 gizzard shad experiments. Only when Daphnia spp. were abundant in enclosures (averaging more than $40 / \mathrm{L}$ during June-July experiments) did we document reduced edible phytoplankton biovolume in enclosures to which we added gizzard shad. This is consistent with observations in northern lakes, where piscivore responses cascade to phytoplankton only when Daphnia spp. are abundant (Carpenter et al. 1987; 
Leibold 1989). Large-bodied zooplankters seem essential for improving water clarity by top-down manipulations.

\section{Management Implications}

We see little potential for reduced gizzard shad abundance to improve reservoir water clarity by top-down forces. Because most reservoir turbidity is inorganic in nature, it probably will be substantially modified only by altered land use practices and improved riparian buffers. Reservoirs also tend to be dominated by small crustacean zooplankton that, even if abundant, probably have little impact on phytoplankton. Finally, gizzard shad may reduce water clarity by consuming sediments and resuspending nutrients that otherwise would be unavailable to phytoplankton, thus increasing phytoplankton biomass (Vanni 1995). It is unrealistic to expect improved water clarity in reservoirs with abundant gizzard shad, small crustacean zooplankton, and agricultural watersheds.

However, some potential exists to reduce gizzard shad populations to the point that zooplankton abundance remains sufficiently high to improve recruitment of planktivorous sport fishes (Dettmers 1995). Sport fishes with early planktivorous life stages frequently suffer poor recruitment when zooplankton abundance falls below $100 / \mathrm{L}$ (Werner and Blaxter 1980; Eldridge et al. 1981; $\mathrm{Li}$ and Mathias 1982). Because gizzard shad in reservoirs appear in the pelagic zone 2-3 weeks before bluegills Lepomis macrochirus and crappies (DeVries and Stein 1992; Welker et al. 1994), they can eliminate zooplankton and reduce recruitment of these sport fishes (DeVries and Stein 1992). Thus, if reservoir managers seek to improve sport fish recruitment, they must reduce gizzard shad to levels that allow zooplankton densities greater than $100 /$ $\mathrm{L}$ during the open-water residence of larval fishes.

Our response surface predicts only a small region where zooplankton abundance persists at densities greater than $100 / \mathrm{L}\left(\log _{e} \cdot 100=4.6\right.$; Figure 6). Only when daily zooplankton productivity exceeds $220 \mathrm{mg} / \mathrm{m}^{3}\left(\log _{e} \cdot 220=5.4\right)$ and age-0 gizzard shad density is less than $10 / \mathrm{m}^{3}\left(\log _{e} \cdot 10=\right.$ 2.3) can zooplankton and gizzard shad coexist. In most Ohio reservoirs, even fewer than 10 gizzard $\mathrm{shad} / \mathrm{m}^{3}$ can eliminate crustacean zooplankton. Historical sampling of 18 reservoirs by the Aquatic Ecology Laboratory (M. T. Bremigan, N. S. Donovan, and J.M.D., unpublished data) and the Ohio Division of Wildlife (M. Austin, personal communication) revealed peak densities of larval gizzard shad below $10 / \mathrm{m}^{3}$ in only 19 of 44 reservoir-years.

Increasing piscivore abundance could reduce gizzard shad abundance, permitting zooplankton to increase in more productive reservoirs. Nevertheless, in Ohio reservoirs, largemouth bass annually consume $30 \%$ or less of the gizzard shad standing crop (Carline et al. 1984). We predict that age- 0 gizzard shad abundance must be driven below $10 / \mathrm{m}^{3}$ for crustacean zooplankton to persist at more than $100 / \mathrm{L}$. Given the above rate of piscivore consumption, age- 0 gizzard shad abundance could not exceed $14 / \mathrm{m}^{3}$ in even the most productive reservoirs if piscivores are to sufficiently reduce gizzard shad and improve sport fish recruitment.

Our historical reservoir sampling revealed that in 25 of 44 lake-years, peak age- 0 gizzard shad abundance was less than $14 / \mathrm{m}^{3}$. Thus, many reservoirs have the potential for increased zooplankton abundance resulting from low age-0 gizzard shad density. However, when one considers zooplankton productivity, this conclusion changes. Our historical sampling indicates that daily zooplankton production in reservoirs exceeded 220 $\mathrm{mg} / \mathrm{m}^{3}$ in only 3 of 10 lake-years (M. T. Bremigan and J.M.D., unpublished data). Given that only Clark Lake enclosures maintained sufficient zooplankton production to sustain abundant zooplankton, we believe that only about 1 of 8 reservoirs might sustain sufficient zooplankton production to permit zooplankton persistence at more than 100 / L. Thus, stocking piscivores in Ohio to reduce gizzard shad abundance probably will not increase zooplankton density to support increased recruitment of sport fishes, except in reservoirs with age0 gizzard shad abundance below $10 / \mathrm{m}^{3}$ and daily zooplankton production above $220 \mathrm{mg} / \mathrm{m}^{3}$.

\section{Acknowledgments}

We thank N. Donovan, J. Francis, K. Jones, E. Lewis, N. Sagalkin, S. Strong Betz, G. Thiede, and L. Yako for their help in the field and laboratory. We also appreciate the efforts of A. St. Amand, who counted phytoplankton. Constructive advice was provided by $\mathbf{M}$. Bremigan, M. Kershner, E. Marschall, and J. Garvey. Comments on earlier drafts by $D$. DeVries, R. Drenner, N. Sagalkin, and M. Vanni substantially improved the paper. This work was funded by Federal Aid in Sport Fish Restoration projects F-57-R and F-69-P, administered jointly by the U.S. Fish and Wildlife Service and the Ohio Division of Wildlife, and by the $\mathrm{Na}$ - 
tional Science Foundation grants DEB-9107173 and DEB-9407859 to R.A.S.

\section{References}

Adams, S. M., and D. L. DeAngelis. 1987. Indirect effects of early bass-shad interactions on predator population structure and food web dynamics. Pages 103-117 in W. C. Kerfoot and A. Sih, editors. Predation: direct and indirect impacts on aquatic communities. University Press of New England, Hanover, New Hampshire.

Bean, D. J. 1980. Crustacean zooplankton production in Lake Erie, 1970. Master's thesis. Ohio State University, Columbus.

Benndorf, J. 1990. Conditions for effective biomanipulation; conclusions derived from whole-lake experiments in Europe. Hydrobiologia 200/201:187203.

Bodola, A. 1966. Life history of the gizzard shad, Dorosoma cepedianum (LeSueur), in western Lake Erie. U.S. Fish and Wildlife Service Fishery Bulletin 65: $391-425$.

Bottrell, H. H., and eight coauthors. 1976. A review of some problems in zooplankton production studies. Norwegian Journal of Zoology 24:419-456.

Bremigan, M. T., E. M. Lewis, M. B. Jones, R. A. Stein, and D. R. DeVries. 1991. Evaluating effects of stocking threadin shad on young-of-year crappie, bluegill, and largemouth bass in Ohio lakes. Ohio Department of Natural Resources, Federal Aid in Sport Fish Restoration, Project F-57-R, Final Performance Report, Columbus.

Carline, R. F., B. L. Johnson, and T. J. Hall. 1984. Estimation and interpretation of proportional stock density for fish populations in Ohio impoundments. North American Journal of Fisheries Management 4:139-154.

Carpenter, S. R., and J. F. Kitchell. 1993. The trophic cascade in lakes. Cambridge University Press, New York.

Carpenter, S. R., and nine coauthors. 1987. Regulation of lake primary productivity by food web structure. Ecology 68:1863-1876.

Culver, D. A., and W. R. DeMott. 1978. Production of zooplankton at nearshore stations in Lakes Ontario and Erie. Inernationale Vereinigung für theoretische und angewandte Limnologie Verhandlungen 20: 252-256.

DeMelo. R., R. France, and D. J. McQueen. 1992. Biomanipulation: hit or myth? Limnology and Oceanography 37:192-207.

DeMott, W. R. 1976. Zooplankton productivity at Locust Point, an inshore area in western Lake Erie. Master's thesis. Ohio State University, Columbus.

Dettmers, J. M. 1995. Assessing the trophic cascade in reservoirs: the role of an introduced predator. Doctoral dissertation. Ohio State University, Columbus.

Dettmers, J. M., and R. A. Stein. 1992. Food consumption by larval gizzard shad: zooplankton effects and its implications for reservoir communities.
Transactions of the American Fisheries Society 121: 494-507.

DeVries, D. R., and R. A. Stein. 1991. Comparison of three zooplankton samplers: a taxon-specific assessment. Journal of Plankton Research 13:53-59.

DeVries, D. R., and R. A. Stein. 1992. Complex interactions between fish and zooplankton: quantifying the role of an open-water planktivore. Canadian Journal of Fisheries and Aquatic Sciences 49:12161227.

DeVries, D. R., R. A. Stein, J. G. Miner, and G. G. Mittelbach. 1991. Stocking threadfin shad: consequences for young-of-year fishes. Transactions of the American Fisheries Society 120:368-381.

Drenner, R. W., F. DeNoyelles, and D. Kettle. 1982a. Selective impact of filter-feeding gizzard shad on zooplankton community structure. Limnology and Oceanography 27:965-968.

Drenner, R. W., W. J. O'Brien, and J. R. Mummert. 1982b. Filter-feeding rates of gizzard shad. Transactions of the American Fisheries Society 111:210215.

Drenner, R. W., J. D. Smith, and S. T. Threlkeld. In press. Lake trophic state and the limnological effects of omnivorous fish. Hydrobiologia.

Dumont, H. J., I. Van de Velde, and S. Dumont. 1975. The dry weight estimate of biomass in a selection of Cladocera, Copepoda and Rotifera from the plankton, periphyton and benthos of continental waters. Oecologia 19:75-97.

Eldridge, M. B., J. A. Whipple, D. Eng, M. J. Bowers, and B. M. Jarvis. 1981. Effects of food and feeding factors on laboratory-reared striped bass larvae. Transactions of the American Fisheries Society 110: 111-120.

Filipek, S. 1982. Survey and evaluation of Arkansas' chemical rehabilitation of lakes. Proceedings of the Annual Conference Southeastern Association of Fish and Wildlife Agencies 34(1980): 181-192.

Guest, W. C.. R. W. Drenner, S. T. Threlkeld, F. D. Martin, and J. D. Smith. 1990. Effects of gizzard shad and threadfin shad on zooplankton and young-ofyear white crappie production. Transactions of the American Fisheries Society 119:529-536.

Hambright, K. D., R. W. Drenner, S. J. McComas, and N. G. Hairston, Jr. 1991. Gape-limited piscivores, planktivore size refuges, and the trophic cascade hypothesis. Hydrobiologia 121:389-404.

Haney, J. F., and D. J. Hall. 1973. Sugar-coated Daphnia: a preservation technique for Cladocera. Limnology and Oceanography 18:331-333.

Johnson, B. M., R. A. Stein, and R. F. Carline. 1988. Use of a quadrat rotenone technique and bicenergetics modeling to evaluate prey availability to stocked piscivores. Transactions of the American Fisheries Society 117:127-141.

Kitchell, J. F. 1992. Food web management: a case study of Lake Mendota. Springer-Verlag, New York.

Kitchell, J. F., and S. R. Carpenter. 1993. Cascading trophic interactions. Pages 1-14 in S. R. Carpenter and J. F. Kitchell, editors. The trophic cascade in lakes. Cambridge University Press, New York. 
Lancaster, H. F., and R. W. Drenner. 1990. Experimental mesocosm study of the separate and interaction effects of phosphorus and mosquitofish (Gambusia affinis) on plankton community structure. Canadian Journal of Fisheries and Aquatic Sciences 47:471479.

Leibold, M. A. 1989. Resource edibility and the effects of predators and productivity on the outcome of trophic interactions. American Naturalist 134:922949.

Li, S., and J. A. Mathias. 1982. Causes of high mortality among cultured larval walleyes. Transactions of the American Fisheries Society 111:710-721.

Luecke, C., L. G. Rudstam, and Y. Allen. 1992. Interannual patterns of planktivory 1987-1989: an analysis of vertebrate and invertebrate predators. Pages 275-302 in J. F. Kitchell, editor. Food web management: a case study of Lake Mendota. SpringerVerlag, New York.

Lyons, J. 1987. Prey choice among piscivorous juvenile walleyes (Stizostedion vitreum). Canadian Journal of Fisheries and Aquatic Sciences 44:758-764.

Maceina, M. J., P. W. Bettoli, and D. R. DeVries. 1994. Use of a split-plot analysis of variance design for repeated-measures fishery data. Fisheries 19(3):1420.

McQueen, D. J., M. R. Johannes, J. R. Post, T. J. Stewart, and D. R. S. Lean. 1989. Bottom-up and top-down impacts on freshwater pelagic community structure. Ecological Monographs 59:289-309.

McQueen, D. J., E. L. Mills, J. L. Forney, M. R. S. Johannes, and J. R. Post. 1992. Trophic level relationships in pelagic food webs: comparisons derived from long-term data sets for Oneida Lake, New York (USA), and Lake St. George, Ontario (Canada). Canadian Journal of Fisheries and Aquatic Sciences 49:1588-1596.

McQueen, D. J., J. R. Post, and E. L. Milis. 1986. Trophic relationships in freshwater pelagic ecosystems. Canadian Journal of Fisheries and Aquatic Sciences 43:1571-1581.

Miller, R. R. 1960. Systematics and biology of the gizzard shad (Dorosoma cepedianum) and related fishes. U.S. Fish and Wildlife Service Fishery Bulletin 60(173):371-392.

Mundahl, N. D. 1991. Sediment processing by gizzard shad, Dorosoma cepedianum (LeSueur), in Acton Lake, Ohio, U.S.A. Journal of Fish Biology 38:565572.

Mundahl, N. D., and T. E. Wissing. 1988. Selection and digestive efficiencies of gizzard shad feeding on natural detritus and two laboratory diets. Transactions of the American Fisheries Society 117:480487.

Orth, D. J. 1980. Changes in the fish community of Lake Carl Blackwell, Oklahoma (1967-77) and a test of the reproductive guild concept. Proceedings of the Oklahoma Academy of Science 60:10-17.

Rudstam, L. G., Y. Allen, B. M. Johnson, C. Luecke, J. R. Post, and M. J. Vanni. 1992. Food web structure of Lake Mendota. Pages 243-273 in J. F. Kitchell, editor. Food web management: a case study of Lake Mendota. Springer-Verlag, New York.

Shapiro, J., and D. I. Wright. 1984. Lake restoration by biomanipulation. Round Lake, Minnesota - the first two years. Freshwater Biology 14:371-383.

Stahl, T. P., and R. A. Stein. 1994. Influence of larval gizzard shad (Dorosoma cepedianum) density on piscivory and growth of young-of-year saugeye (Stizostedion vitreum $\times S$. canadense). Canadian Journal of Fisheries and Aquatic Sciences 51:19932002.

St. Amand, A. L. 1990. Mechanisms controlling metalimnetic communities and the importance of metalimnetic phytoplankton to whole lake primary productivity. Doctoral dissertation. University of Notre Dame, Notre Dame, Indiana.

Stein, R. A., D. R. DeVries, and J. M. Dettmers. In press. Food-web regulation by a planktivore: exploring the generality of the trophic cascade hypothesis. Canadian Journal of Fisheries and Aquatic Sciences.

Summers, G. L., and J. R. Axon. 1980. History of the Barkley Lake rotenone study. Proceedings of the Annual Conference Southeastern Association of Fish and Wildlife Agencies 33(1979):673-679.

Vanni, M. J. 1995. Nutrient transport and recycling by consumers in lake food webs: implications for algal communities. Pages 81-95 in G. A. Polis and K. O. Winemiller, editors. Food webs: integration of patterns and dynamics. Chapman and Hall, New York.

Vanni, M. J., C. Luecke, J. F. Kitchell, and J. J. Magnuson. 1990. Effects of planktivorous fish mass mortality on the plankton community of Lake Mendota, Wisconsin: implications for biomanipulation. Hydrobiologia 200/201:329-336.

Vondracek, B., and R. LeHew. 1991. Population dynamics and ecology of Lake Erie gizzard shad. Ohio Department of Natural Resources, Federal Aid in port Fish Restoration, Project F-6I-R, Final Performance Report, Columbus.

Wahl, D. H., and R. A. Stein. 1988. Selective predation by three esocids: the role of prey behavior and morphology. Transactions of the American Fisheries Society 117:142-151.

Welker, M. T., C. L. Pierce, and D. H. Wahl. 1994. Growth and survival of larval fishes: roles of competition and zooplankton abundance. Transactions of the American Fisheries Society 123:703-717.

Werner, R. G., and J. H. S. Blaxter. 1980. Growth and survival of larval herring, Clupea harengus, in relation to fry density. Canadian Journal of Fisheries and Aquatic Sciences 37:1063-1069.

Willis, D. W., and L. D. Jones. 1986. Fish standing crops in wooded and nonwooded coves of Kansas reservoirs. North American Journal of Fisheries Management 6:105-108.

Received December 8, 1994 Accepted July 31, 1995 